\title{
Responsabilidade ética e social na produção de periódicos científicos
}

\section{Joana Coeli Ribeiro Garcia}

\author{
Doutora em Ciência da Informação, \\ Universidade Federal do Rio de Janeiro - \\ RJ; Professora da Universidade Federal \\ da Paraíba
}

Maria das Graças Targino

\section{Pós-Doutora em Jornalismo; Instituto Interuniversitario de Iberoamérica da Universidad de Salamanca}

A partir dos conceitos de ética e responsabilidade social, discute-se o exercício dos atores sociais envolvidos com a produção de periódicos e artigos científicos. Responsabilidade social é integrada por princípios éticos, valores morais e contexto cultural para desempenhar atividades práticas, políticas e comportamentos esperados (no sentido positivo) ou proibidos (no sentido negativo) por membros da sociedade, independente de prescrição em códigos de ética. Com base nessa representação, analisam-se situações em que autores, editores $e$ avaliadores se deparam com dilemas éticos, os quais podem ser minimizados com a prática da auto-ética, de forma a atingir a ética para com o outro, em qualquer ambiente, impresso, eletrônico ou digital. Este parece ser o caminho que conduz à observância de preceitos éticos e ao exercício da responsabilidade social, ainda que as dúvidas sempre persistam diante da impossibilidade de generalizações.

Palavras-chave:

Responsabilidade

ética;

Responsabilidade social; Responsabilidade do editor. Responsabilidade do autor; Responsabilidade do referee; Produção científica.

\section{Ethics and social responsability in the production of scientific journals}


Taking into account the concepts of ethics and social responsibility, the role of the social actors involved in the production of scientific journals and articles is discussed here. Social responsibility is made of ethical principles, moral values and cultural contexts to develop activities, practices, policies and behaviors that are expected from (in a positive way) or forbidden to (in a negative way) members of the society without the need of being determined by ethical codes. Based on this representation, some situations are analyzed in which authors, referees, and editors are faced with ethical dilemmas that could be minimized by the practice of selfethics towards the other, in any media, be it written, digital or electronic. This seems to be the way that lead to ethical principles and to the practice of social responsibility despite all dilemmas that may persist when faced with the impossibility to generalize.

Keywords: Ethics responsibility; Social responsibility; Editor's responsibility; Author's responsibility; Referee's responsibility; Scientific production.

Recebido em 17.10.2007 Aceito em 06.03.2008

\section{Introdução}

Nos dias atuais, ética e responsabilidade social são expressões utilizadas com freqüência pelos mass media. As pessoas, em todos os níveis, se habituam a conviver com elas e as utilizam no dia-a-dia. Isso porque o impacto da globalização econômica torna mais visível a estratificação social e a quantidade de excluídos; amplia a preocupação com princípios éticos e valores morais em instituições e organizações em geral; exige das empresas solidificação de imagem positiva perante o público; e, sobretudo, espera da sociedade concordância com parâmetros éticos explícitos ou implícitos, ou seja, ações éticas de parte a parte. Vai mais além. Interfere na atuação das categorias profissionais, independente dos códigos de ética existentes. A responsabilidade de uns perante os outros permeia a sociedade como exigência comportamental, ainda que, paradoxalmente, sempre existam dificuldades de se chegar a um consenso e as opiniões se diversifiquem de forma quase infinita, por distinções culturais, sociais e individuais. Há, sempre, dois lados da mesma moeda: um que assume atitude ética; um outro que não assimila essa atitude como tal e se considera vítima de eventual injustiça.

Violações graves ou leves perfazem 0 cotidiano do homem contemporâneo. De uma forma ou de outra, em determinado momento de vida, cometemos infrações contra preceitos éticos estabelecidos. A colocação de nosso nome ou de um colega em trabalho de equipe, mesmo 
sem a participação efetiva ou a aceitação velada de que os alunos o façam. A apresentação do mesmo trabalho em eventos distintos, graças ao artifício de mudanças mínimas na parte introdutória. A indicação de colega menos habilitado para comissão de concurso público ou similar, em detrimento do profissional mais qualificado e menos "colega" etc.

E mais, no lastro da citada globalização e da explosão das tecnologias de informação (TICs), que afeta, de forma radical, todos os segmentos da vida social, na atualidade, os dilemas éticos, mais do que antes, atingem a produção intelectual e / ou científica dos indivíduos das distintas áreas do conhecimento. Há mais facilidade de divulgação dos novos saberes e de acesso às informações, rompendo barreiras espaciais e geográficas, mas, em contraposição, a sagacidade e astúcia para fraudes se fazem mais presentes na ciência e tecnologia (C\&T), na academia e em qualquer outra instância.

O cientista, como os demais seres humanos, nem está isento de imperfeições nem se despe de sua escala de valores no exercício das funções desempenhadas. Isto seria pensar em neutralidade da ciência, perspectiva irreversivelmente ultrapassada. Ao contrário. É imprescindível perceber ciência e conhecimento científico como produção de indivíduos falhos. Carregam consigo intrínseca carga ideológica, representada por valores singulares referentes à ética e à responsabilidade social. Daí, paradoxalmente, enquanto o pesquisador luta para conseguir credibilidade e aceitação (o que só é possível com a aprovação de sua produção pelos pares; da mesma forma que a reputação da comunidade científica como um todo depende da credibilidade dos membros, individualmente), 0 número de embustes cresce entre os atores responsáveis pela produção e comunicação científica.

Porém, é insensatez afirmar que globalização e TICs são responsáveis pelos desvios éticos da produção científica. Há tão-somente maior facilidade para a falsificação, a adulteração ou a apropriação da criação do outro, além de maior probabilidade de equívocos editoriais. Embuste e falcatrua sempre existiram no processo de criação e de editoração, mesmo no contexto da produção científica não eletrônica. $E$, em oposição ao que se pensa a princípio, computador e internet podem agir como armas valiosas para detectar fraudes, mediante estratégias variadas e adaptáveis a situações distintas. É o que Tantam (1991) comprova, ao descrever a experiência do Serious Fraud Office, concebido e operacionalizado pela Roskill Commission, ainda nos anos 80 e em ação até hoje ${ }^{1}$.

E é evidente que registros sobre fraudes e má-conduta, envolvendo a produção e divulgação de textos, atingem a comunidade científica nacional e internacional. Kochan e Budd (1992), por exemplo, relatam o famoso caso do norte-americano John Darsee, nos anos 80, flagrado "fabricando" dados de numerosos artigos científicos, os quais alcançaram o elevado índice de 328 citações, entre 1982 e 1990, no renomado Science Citation Index. Uma coordenadora de pós-graduação do Instituto

\footnotetext{
${ }^{1}$ Disponível em <www.sfo.gov.uk>. Acesso em: 13 mar. 2008.
} 
de Psicologia da Universidade de São Paulo, na década de 90, compila de especialistas nacionais e internacionais um terço de capítulo de livro sob sua autoria: 140 linhas transcritas literalmente e 35 parcialmente (ALTMAN, 1994). Há, ainda, escândalo de dimensão mundial, descrito por Knobel (2003): jovem alemão, Hendrik Schön, 32 anos, vinculado aos renomados laboratórios Bell, New York, é cotado para o Prêmio Nobel de Física, até que, em 2002, comissão de investigação atesta que 16 de 25 trabalhos publicados, de 1999 a 2001, são meras falsificações.

Há muito mais. Considerado um dos nomes centrais da pesquisa com células-tronco, o coreano Woo-Suk Hwang, apontado para o Prêmio Nobel de Genética, foi denunciado por um ex-parceiro. Em dezembro de 2005, o mundo tomou conhecimento do inquérito e este se revelou procedente. Os dados da pesquisa foram alterados, como admitido por Hwang. Os editores da Science, uma das mais prestigiosas revistas científicas do mundo, retrataram-se perante a comunidade científica pela publicação, com significativa repercussão, de artigo produzido pela equipe de pesquisa liderada pelo coreano. A partir desse fato, a também renomada Nature, que editara outro documento do mesmo grupo, no caso sobre a primeira clonagem de um cachorro, partiu para investigar o relato. Há, inclusive, denúncias de que Woo-Suk ilustrava suas matérias com fotos de outros experimentos. (ESTE homem é um ..., 2006).

A partir do exposto, é objetivo deste artigo discutir o exercício dos atores sociais envolvidos com a produção científica, a partir dos conceitos de ética e de responsabilidade social, com destaque para títulos de periódicos / revistas técnico-científicas ou científicas, incluindo as revistas acadêmicas que seguem preceitos científicos ${ }^{2}$. Face à impossibilidade de incorporar todos os envolvidos, a ênfase recai nos procedimentos do autor, do editor e do avaliador. Isto permite, após explanação acerca de expressões em si mesmas controversas, tais como ética, moral e responsabilidade social, retomar questões alusivas aos atores mencionados.

\section{Ética e responsabilidade social}

Não obstante explanações e discussões anteriores, a priori, é imprescindível rever os conceitos em pauta, para melhor contextualização. Ética, como a etimologia sugere, é o ramo da filosofia que se ocupa da reflexão sobre os costumes, englobando diretrizes e parâmetros destinados a apreciar a emissão de juízos de valor diante da prática do bem e do mal. É a sistematização da teoria da ação. Moral, por sua vez, integra a deontologia, enquanto ciência do dever, designando preceitos doutrinários ou códigos relativos às diversas profissões. Refere-se aos

2 Inexiste consenso na classificação do que é ou não científico. Hoje em dia, porém, aceitam-se os preceitos adotados pelo Instituto Brasileiro de Informação em Ciência e Tecnologia (IBICT): (a) títulos científicos, mais de $50 \%$ do conteúdo são artigos assinados resultantes de pesquisas científicas; (b) títulos técnicos, mais de $50 \%$ são artigos assinados, emitindo comentários, opiniões e pontos de vista; (c) títulos de divulgação priorizam notícias curtas, informes e similares. 
atos e costumes per se, ou seja, ao conjunto de normas objetivas de conduta, mutáveis no tempo e no espaço em concordância com os contextos culturais. Morin (2005, p. 98) utiliza a distinção de Nietzsche entre moral e moralina. Esta última "[...] julga e condena baseada em critérios exteriores ou superficiais de moralidade, apropria-se do Bem e transforma em oposição entre bem e mal aquilo que, na realidade, não passa de conflito de valores." No cotidiano, porém empregamos a expressão ética profissional ou simplesmente ética, para nomear as normas de conduta que definem direitos e deveres dos que atuam em diferentes campos, incluindo, portanto, a produção de revistas científicas.

Para Fourez (1995) inexistem normas de conduta eternas ou indicativas de situações indistintas. Diante da impossibilidade de se produzir códigos de ética que reúnam as atividades desempenhadas pelo ser humano em sua globalidade, ou códigos que especifiquem todos os comportamentos ideais, os princípios éticos e valores morais culminam com o estabelecimento de atividades que aderem a critérios socialmente éticos ou socialmente responsáveis. Tais critérios podem ser alusivos às categorias profissionais, às empresas e instituições e aos indivíduos em particular. Envolvem responsabilidades econômicas, legais, éticas, morais e sociais, em qualquer situação. No caso dos profissionais, em meio aos colegas. No caso das organizações, frente a seus membros, acionistas e clientes, dentro do prescrito por Veloso (2006, p. 05), quando diz: "[as] responsabilidades éticas correspondem a atividades, práticas, políticas e comportamentos esperados (no sentido positivo) ou proibidos (no sentido negativo) por membros da sociedade, apesar de não codificados em leis."

Membros da sociedade civil exercitam responsabilidades éticas entre si e também desfrutam de atividades na esfera de órgãos públicos, empresas privadas, corporações, categorias profissionais, na sociedade como um todo, perante o Estado e os povos. Nesse ínterim, o indivíduo desenvolve o que Morin (2005, p. 92) denomina de auto-ética, formada "no nível da autonomia individual, para além das éticas integradas e integrantes, embora raízes ou ramos dessas éticas permaneçam, muitas vezes, no espírito individual". Trata-se do princípio altruísta de inclusão, do apelo de solidariedade em relação aos seus e à comunidade, aos quais se obedece, às vezes, quase intuitivamente, sem muita reflexão. Outras vezes, mediante análise, para decidir o comportamento a ser adotado em consonância com sua autonomia de espírito.

Para o autor supra, essa dualidade do ser humano fragiliza a autonomia ética e dificulta seu discernimento, uma vez que vivenciamos muito mais a angústia das incertezas éticas do que a plenitude da responsabilidade social e da sensação de dever cumprido. A ética, quando reduzida aos códigos, conduz a julgamentos maniqueístas, em que o mal se contrapõe ao bem, o errado ao certo, o antiético ao ético e assim por diante. E ainda que desenvolva a auto-ética, o indivíduo não se liberta por inteiro das raízes que permanecem no espírito individual.

Logo, o homem necessita exercitar a ética de si para si, o que comporta auto-análise, autocrítica, honra, tolerância, prática da recursão ética, luta contra a moralina, resistência à lei de talião e tomada de 
responsabilidade. $\mathrm{E}$, ainda, uma ética da compreensão que considere a consciência da complexidade e dos desvios humanos e a abertura à magnanimidade e ao perdão, ao lado de uma ética da cordialidade e uma ética da amizade. Esses elementos conjugados possibilitam que a ética iniciada no âmago do indivíduo, dele para consigo, se aprimore e atinja a ética para com o outro, o que exige "trabalhar pelo pensar bem e pelo pensar-se bem", para "compreender-se e corrigir-se o que constitui simultaneamente, um princípio de pensamento e uma necessidade de ética" (MORIN, 2005, p. 93). Os imperativos de solidariedade, hospitalidade e honra advindos da inter-relação entre religião, laços familiares, grupos sociais e contextos culturais fazem com que cada ser humano os receba como inevitáveis, e, simultaneamente, como possessão. Possessão, na concepção de estado em que corpo ou mente são "possuídos" por entidades exteriores, que podem ser forças, valores ou imperativos.

No caso do autor, do editor e do avaliador, que atuam na esfera das revistas técnico-científicas ou científicas, a responsabilidade social pode ser exemplificada em diversificadas atribuições, que visam, invariavelmente, publicizar os conhecimentos recém-gerados, dentro da denominada comunicação científica. Esta possibilita ao produto (produção científica) e aos produtores (pesquisadores) visibilidade e possível credibilidade no meio social em que produto e produtores se inserem. De forma mais ampla, suas responsabilidades éticas se estendem à sociedade em geral, o que justifica a expressão responsabilidade social para nomear a atuação desses profissionais como agentes sociais e, sobretudo, seu nível de consciência em relação aos atos que praticam em meio à tessitura social. Isto porque, se é compreensível que a divulgação de resultados se inicie no âmago da própria comunidade científica, é inviável restringir a comunicação à troca de informações entre cientistas. É preciso superar a tendência da comunicação somente para e entre cientistas. Se a comunicação científica é básica àqueles que fazem ciência, a produção da C\&T não se dá alheia ao contexto social em que se insere. Como sistema social, a ciência deve ultrapassar as fronteiras da comunidade de usuários mais imediatos rumo ao grande público, sob o risco de se tornar desnecessária e inútil.

Então, enquanto autor, editor e avaliador têm sua responsabilidade social ampliada quase infinitamente, os dilemas éticos enfrentados também se estendem. Não importa se os produtos estão em formato impresso ou eletrônico. A essência da comunicação científica é definida não pelo suporte físico em si, mas pelo conteúdo das mensagens veiculadas, de modo que as revistas científicas eletrônicas não abram mão do controle de aferição de qualidade, que traz subjacente, de forma idêntica, responsabilidade ética e social.

\section{O autor entre responsabilidades e dilemas}

Como detalhado por estudiosos de especialidades distintas, como Roland Barthes, Ítalo Calvino, M. Foucault e Umberto Eco, e sintetizadas 
por Targino (2005), o conceito de autoria está em flagrante mutação ou desconstrução. A princípio, a autoria remetia à individualidade, ou seja, à identidade formalizada do autor em suposta objetividade. Objeto e sujeito não se fundiam em nenhum momento. A produção intelectual era percebida como única, original, íntegra e permanente, além de idealizada segundo preceitos éticos, sociais e jurídicos em perfeita sintonia com o Estado e com as exigências mercadológicas.

Hoje, essa concepção não se sustenta. Em primeiro lugar, a pretensa individualidade dá lugar a obras resultantes do esforço conjunto de um grupo de criadores, entre escritores, produtores, artistas, músicos, fotógrafos e outros. Como inevitável, nem esses modos de expressão nem essas produções, nem sua leitura se dão de forma linear e unívoca. A conjunção de atores envolvidos na autoria vai além da produção cultural. Alcança a produção e editoração científica. Mais e mais, há nítido pluralismo de teorias e paradigmas científicos que sobrevivem lado a lado, além de mobilidade e redefinição crescente da verdade científica, confirmando a ciência como fenômeno social e a produção de artigos e revistas como termômetro da temporalidade dos achados científicos e, daí, da evolução da C\&T.

Reiteramos, ainda, a impossibilidade de os autores dos textos científicos negarem a ideologização da ciência. Se o fazem, contestam sua condição de ser humano, como vimos. Ideais, crenças e valores estão intrinsecamente enraizados ao seu ser, saber e fazer. Resta, então, ao autor, no papel de cientista ou pesquisador, uma só opção: " 'domar' a carga ideológica que carrega consigo, para impedir que contamine pesquisas e resultados. É reconhecer sua existência e o dano que representa para a produção científica, sem deixar, no entanto, se vencer por ela." (TARGINO, 2005, p. 39). Em terceiro lugar, pensar a autoria ligada à produção como única e original renega a dinamicidade e interinidade da ciência, como processo permanente de construção. Isto é, a autoria de qualquer texto, no âmbito da ciência, lança mão de conhecimentos preexistentes, a tal ponto que a originalidade em ciência é sempre relativa, nunca absoluta.

É o que Barthes (1998) tanto enfatiza. Todo discurso, ao mesmo tempo em que pretende comunicar ou produzir sentido, tende a repassar valores ideológicos; porquanto o autor é, antes de tudo, sujeito social, e, como tal, historicamente construído. Configura-se como produto do ato de escrever (artigos ou não). É o ato de escrever que forja o autor e não o autor que forja o ato de escrever:

[...] um texto não é feito de uma linha de palavras a produzir um sentido único, de certa maneira teológico (que seria a "mensagem" do Autor-Deus), mas um espaço de dimensões múltiplas, onde se casam e se contestam escrituras variadas, das quais nenhuma é original (grifo nosso): o texto é um tecido de citações, saídas dos mil focos da cultura [...] 0 escritor só pode imitar um gesto sempre anterior, jamais original [...] (BARTHES, 1998, p. 68-69) 
Sob esta ótica, o racionalismo de Kant e o absolutismo de Hegel são agora substituídos por formas de pensar mais livres e flexíveis, que distanciam o cientista de uma visão dionisíaca ou da falsa idéia de transcendência e de superioridade em relação à natureza. Para Antonio (2001), é como se a sociedade contemporânea retomasse as rédeas do iluminismo ou filosofia das luzes (século XVIII), caracterizado, ao mesmo tempo, pela confiança no progresso e na razão, mas, sobretudo, pelo incentivo à liberdade de pensamento, em consonância com o racionalismo, que privilegia o cognoscível pela razão ou inteligência. Vivenciamos a oportunidade de conviver com múltiplas verdades, uma vez que 0 processo de autoria acompanha as transformações contínuas da sociedade, as quais incorporam mutações de parâmetros éticos, dentro do previsto por Fourez (1995) e Morin (2005).

Como eles asseguram, é impossível prescrever normas de conduta universais e atemporais. Porém, ao tempo em que as TICs e os múltiplos recursos do hipertexto inovam e incrementam a produção editorial, em termos de C\&T, não podemos atribuir às inovações tecnológicas a responsabilidade de infração à ética, como apregoado por alguns acadêmicos e estudiosos, a exemplo de Kucinski (2005). Brilhante, ao alertar sobre o contra-senso de se imputar às inovações tecnológicas a responsabilidade da exclusão digital, o que corresponderia a atribuir a Gutenberg, com seus tipos móveis de impressão, o analfabetismo, surpreendentemente, apregoa o "código de plágio":

Com a internet modifica-se [...] o caráter da pesquisa bibliográfica e documental. A facilidade de localizar os temas na world wide web, de copiar e misturar trabalhos e deles se apropriar $[\ldots]$, assim como o anonimato do contato e do pagamento abriram caminho à prática da fraude intelectual, da cópia de trabalhos e de idéias [...] Pode ser que se redefina o que é uma pesquisa acadêmica, com o abandono do critério de originalidade (grifo nosso) e paternidade das idéias em troca de um critério de competência na busca [...] (KUCINSKI, 2005, não paginado).

$\mathrm{Na}$ verdade, não pretendemos negar a intertextualidade ou a polifonia que caracterizam os textos, científicos ou não. Reconhecemos que o cientista / pesquisador / autor contemporâneo das revistas técnicocientíficas acionam outras vozes e outros textos. No entanto, defendemos, com veemência, que ele não pode excluir dessas "recriações" cuidados éticos e responsabilidades social, tais como: respeito à autoria das fontes utilizadas; autocitação moderada; autenticidade dos dados relatados; texto bem cuidado e fidedignidade ao pensamento dos demais especialistas. Sobre este último item, a literatura científica registra casos de má interpretação ou de distorção para aproximar as idéias do autor fonte com o que está sendo produzido, como exemplificado por Wilson (2006, p. 38). Para ele, "a distinção feita por Nonaka e Takeuchi entre conhecimento tácito e explícito é uma corrupção ilegítima da idéia de 
conhecimento tácito feita por Polanyi", identificando o ponto em que, em sua opinião, a interpretação deixa de ser verdadeira.

Dizendo de outra forma, as mutações que se dão no campo da autoria não endossam atitudes aéticas. Indicam que qualquer obra é sempre e irreversivelmente uma obra aberta (ECO, 1990) e que permite leituras variadas, o que constitui forma de interação. Na mesma linha de pensamento, Foucault (1992) afirma que qualquer texto é capturado num sistema de referências com outros textos postos na internet, onde há infinitos espaços e "mundos impossíveis". Essa intervenção agiliza o acesso à informação e transmuta o leitor em construtor de sentidos, reduzindo a autonomia dos escritos, e, por conseguinte, dos próprios autores, acentuando o entrelaçamento entre as funções de autor e as de leitor, mas não ditando a "morte do autor", como emerge em discussões acadêmicas, à semelhança das idéias apregoadas por Kucinski (2005).

Afora essa questão central, há, ainda, o caso do autor que, pressionado para divulgar seus resultados de imediato, erroneamente encaminha o trabalho para mais de um periódico a um só tempo. Configura-se como procedimento, de novo, discutível do ponto de vista ético. Le Coadic (1996, p. 35) afirma ipsis litteris que "[...] no terreno formal, o pesquisador está obrigado, por um código tácito de deontologia, a publicar a informação apenas uma vez, em um único artigo." Meadows (1999, p. 164), em oposição, também com palavras textuais, assegura ser "[...] possível reportar oralmente uma mesma pesquisa mais de uma vez, mas ela também pode aparecer em mais de um tipo de publicação." São pontos de vista divergentes, de modo que o autor precisa considerar a exigência da quase totalidade das revistas para que os manuscritos não sejam remetidos a outros veículos.

No que se refere às comunicações ou aos trabalhos apresentados em eventos científicos, é possível publicação posterior em revista. 0 argumento usual é o de que, no decorrer desses acontecimentos, a pesquisa é discutida. Recebe críticas, positivas ou negativas, que podem ser aceitas ou rejeitadas, conduzindo a reformulações - acréscimos, supressões, correções, mudança de enfoque etc. Em segundo lugar, o artigo, ainda que registrado em anais (não importa o suporte), integra a literatura cinzenta, ou seja, mantém circulação restrita. Isto é, a apresentação nos encontros ou o registro nos anais não retira o ineditismo, e o artigo pode ser reeditado em revista de circulação ampla, mediante nota indicativa em rodapé sobre a publicação anterior.

Mesmo assim, esse veredicto é questionável, como qualquer outro, face aos preceitos teóricos que regem a ética e a moral. Para Fourez (1995), a afirmação social da C\&T na contemporaneidade e o reconhecimento de sua relevância no processo desenvolvimentista das nações põem em evidência a inter-relação ciência, poder e sociedade. Como decorrência, a comunidade científica fortalece-se como grupo social e tenta legitimar sua produção junto à sociedade. Essa busca de legitimação, se apóia num contexto sociocultural, educacional, econômico, político, organizacional, que não pode ser unívoco. Daí, ser sempre passível de polêmicas e discordâncias. 
Por outro lado, não restam dúvidas sobre a natureza da ciência como conhecimento público. Por conseguinte, deve estar à disposição dos cidadãos, indistintamente, o que traz à tona a expansão do jornalismo científico, como recurso para "traduzir" a linguagem científica em diálogo acessível. Os resultados da pesquisa não pertencem ao cientista, mas à humanidade. Constituem produto da colaboração social, e como tal devem ser partilhados com todos, sem privilegiar segmentos ou pessoas. Corresponde ao que Rousseau (2006) denomina, à época, de pacto social ou contrato social: os pesquisadores se comprometem a divulgar os saberes recém-produzidos, advindos, quase sempre, de financiamentos concedidos pelo Estado. É o momento de permitir que a sociedade avalie a adequação da utilização dos recursos e, concomitantemente, usufrua dos avanços da ciência.

No entanto, com a pesquisa concluída, pode surgir outro dilema: há os que não querem divulgar seu trabalho; há os que não podem ou não devem. Na última condição, estão os autores das pesquisas tecnológicas, que devem ser propaladas somente após a adoção das providências de garantia do monopólio, quando são, por fim, amplamente publicadas, dentro do processo esperado de transferência de conhecimentos. Mesmo assim, tanto na ciência como na tecnologia, há quem não publique por decisão individual e personalíssima, indiferente às formas de pressão e de admoestação institucional ou social (GARCIA, 2007).

\section{É a vez do editor...}

Compete ao editor das revistas científicas inúmeras responsabilidades, que variam em consonância com as singularidades de cada título e com a formação da equipe. De acordo com texto de Meadows (1999), as grandes revistas mantêm editor científico e managing editor (editor gerencial). Em termos ideais, ao primeiro cabe, essencialmente, a seleção / avaliação dos conteúdos, enquanto o segundo é o responsável pela editoração em si, com base na premissa de que os cientistas não têm familiaridade com a preparação técnica de originais. Em termos de Brasil, raramente identificamos essa dualidade, inclusive, no campo da ciência da informação.

Vemos, pois, ser impossível generalizar as atribuições do editor. Mesmo assim, com o intuito somente de sistematização, citamos, de forma concisa, as mais freqüentes: definir o perfil básico e a linha de atuação do periódico; criar políticas e projetos editoriais renovadores; representar, formalmente, o título, sempre que necessário; presidir as reuniões da comissão editorial (ou equivalente); acompanhar o mandato dos membros desse comitê; definir os membros do conselho consultivo; assegurar sistema de avaliação ágil, construtivo e interativo; executar as políticas orçamentária e financeira; negociar fontes de financiamento para a publicação; administrar o título para que se torne auto-sustentável ou lucrativo; realizar acordos sobre compra e venda dos direitos de reprodução; estimular a produção de originais, atraindo autores e textos 
de alta qualidade; traçar diretrizes de divulgação do título, com ênfase para a indexação em bases de dados e / ou inserção em portais de periódicos; participar de feiras de livros, sessões de autógrafos e outros eventos; apresentar relatórios sistemáticos à entidade mantenedora; manter a publicação dentro de linha independente e abrangente; acompanhar os critérios de avaliação dos periódicos, na esfera nacional e internacional.

Diante dessa multiplicidade de atribuições, é natural que problemas éticos surjam e ressurjam com força total, o que justifica seis questionamentos levantados por Greene (1999), aplicáveis ora ao editor, ora ao avaliador, como diluídos ao longo do texto, a seguir. Ao receber o artigo, a princípio, o editor avalia-o, observando a adequação aos objetivos e às normas do título. Pode aceitá-lo ou solicitar reformulações. Pode recusá-lo por discordância à linha editorial ou à estruturação prescrita. Em qualquer situação, é o editor a primeira pessoa que entra em contato com os originais no processo de divulgação científica.

A seguir, seleciona os avaliadores dentre os colaboradores do periódico, segundo a proximidade temática. No sistema double blind review (sistema duplamente "cego"), o mais adotado na atualidade, nem o autor conhece o avaliador nem o avaliador (denominamos, também, de árbitro e assessor) conhece o autor. O editor é a única pessoa que identifica autores e avaliadores. Conseqüentemente, de imediato há o entendimento de que é aético o editor publicar no periódico em que exerce essa função, o que responde à primeira questão de Greene (1999) - O editor responsável pode publicar em "sua" editora? Ao não publicar em "sua" revista, prima pela qualidade e imagem ética da publicação, e, por conseguinte, da instituição que a financia.

No entanto, reiterando a impossibilidade de ética universal ou de comportamentos padronizados, tal atitude pode ser interpretada como desconsideração com o veículo ou falta de apreço. $\mathrm{E}$ também há revistas que mantêm seções com editores específicos e praticamente independentes, como no caso da Revista Brasileira de Ciências da Comunicação. Nesses casos, a princípio, não parece inconveniente que um editor submeta seu original a outra seção de "sua" publicação. Ademais, há que se convir que a fronteira da ciência, nas distintas áreas, é dominada por um grupo reduzido de pesquisadores ativos, que constituem a elite. São quase sempre eles os convidados para desempenharem a função de editor ou avaliador, de modo que se essa "proibição" for seguida à risca, estarão limitados a divulgar a própria produção, o que consiste em disparate. Restam bom senso e capacidade de discernimento para que o editor não publique excessivamente naquele título, mas que, em certo momento, possa fazê-lo.

Prosseguindo, ante a provocação de Greene (1999) para contestar outra indagação - Como decidir o que deve ser avaliado localmente ou não? - a seleção dos árbitros se inicia com a decisão do que deve ser examinado por membros locais e externos: regra geral, os textos de autores da instituição devem ser analisados por pessoas externas, por conta da facilidade de identificação de autoria. Isto pode interferir na 
emissão do parecer a depender dos laços de amizade (ou não) existentes. O editor recorre, então, a assessores ad hoc, especialmente convidados tanto para os artigos provenientes de autores institucionais como para temáticas muito específicas.

Mas, como se dá com as demais normas de conduta, não se trata de regra universal. Há que se considerar a situação de comunidades altamente especializadas e que incluem número restrito de membros, de modo que autores e avaliadores inevitavelmente se conhecem ou, no mínimo, identificam os respectivos objetos de estudo. Para minimizar o impasse, resta o uso da auto-ética em prol da ética para o outro, dentro do prescrito por Morin (2005), como resistência à lei de talião. Independente da variação terminológica - lei de talião, pena de talião, talião, retaliação -, originalmente essa expressão referia-se à vingança de um delito, infligindo ao delinqüente o mesmo dano por ele praticado.

$\mathrm{E}$ ainda hoje há denúncias de avaliações que deixam de lado o mérito científico do trabalho para exercitar a "vingança" contra autores cuja identidade é possível de ser imaginada; o que se percebe, algumas vezes, em pareceres radicalmente distintos entre os avaliadores, o que pode ser indício de algo obscuro. No ambiente impresso ou eletrônico, é desejável que o talionato ceda lugar à adoção ética de compreensão, cordialidade e respeito mútuo entre autores / editores / avaliadores, tal como recomendado implicitamente por títulos e editores de periódicos, em busca de pareceres consistentes e não ofensivos, sem que signifique aceite de quaisquer originais em prol da prática perniciosa de favoritismo ou protecionismo.

No que se refere aos conteúdos, a terceira pergunta de Greene (1999) - O editor responsável pode publicar textos que contradizem outros já editados? - é menos polêmica. Os autores devem ser estimulados a produzir artigos que discordem e contrariem idéias divulgadas, objetivando fortalecer a ruptura de paradigmas, proporcionar discussões teóricas e ampliar a produção de novos conhecimentos nas respectivas áreas. O contrário deve ser evitado, ou seja, artigos com abordagens teóricas e metodológicas semelhantes, sem nada de inovador. Estes pouco ou nada acrescentam ao conhecimento estabelecido, ocupando espaço gráfico nos periódicos, distantes de contribuição efetiva; muito embora esses casos impliquem julgamentos distintos e subjetivos por parte dos árbitros.

Após a avaliação, segue-se a divulgação do conhecimento gerado, sem a qual o ciclo não se completa. É o momento de conceder visibilidade à ciência como traço imprescindível, e que favorece a respeitabilidade do veículo e da entidade-editora, como Packer e Meneghini (2006) argumentam. A produção científica é por si critério relevante de avaliação das instituições de ensino superior (IES) e dos institutos de pesquisa, na dita sociedade de informação, cuja característica é a dinâmica do conhecimento. A possibilidade de aferição da qualidade do conteúdo, ainda que submetida a priori aos avaliadores, só ocorre efetivamente a posteriori, por meio de bases de dados, as quais monitoram a qualidade dos periódicos, e por meio dos leitores, que tendem a ser fiéis ao título da 
revista ou ao autor, quando estes suprem suas expectativas éticas e de responsabilidade social. Quer dizer, a produção de artigos e revistas científicas se assemelha àquela de qualquer produto de consumo, com sua marca e a empresa que o produz.

Tudo isto evidencia como as funções do editor se alternam entre responsabilidades delimitadas e dilemas inesperados. A edição de artigos prevê situações variadas, entre as quais oscilam plágios; co-autorias irresponsáveis; temas explorados de forma repetitiva ou equivocada; avaliações às pressas; coação para publicar textos de algumas "grandes figuras" da instituição; e desobediência aos prazos fixados. Resumindo, a eventual falta de ética no âmbito da pesquisa e da publicação científica não se limita às falhas dos procedimentos autorais. Alcança as práticas editoriais e segue pela avaliação. A prova está nas providências das revistas Science e Nature ante a má-conduta de Woo-Suk Hwang e o reconhecimento imediato de "conivência" no episódio, ainda que de forma involuntária.

\section{O avaliador, ele também: entre responsabilidades e dilemas}

Como é possível vislumbrar no item anterior, algumas das indagações de Greene (1999) se aplicam ao avaliador propriamente dito. A submissão do artigo frente à política editorial do periódico está sob o encargo dos pares dentro do sistema de peer review (revisão de pares) ou refereeing (sistema de arbitragem), com destaque para o mencionado double blind review. O certo é que a avaliação consista em elementochave para a distinção entre literatura formal e informal, literatura científica e não científica. Remonta, eventualmente e informalmente, ao início do século XIX, consolidando-se como prática generalizada após a Segunda Guerra Mundial, diante do fluxo informacional e da especialização crescentes, mesmo enfrentando objeções e sendo objeto de controvérsias.

Para Davyt e Velho (2000), a avaliação no âmbito da produção científica se compara à função dos juízes encarregados de analisar e manter o desempenho dos sistemas sociais. Além do mais, a tendência para julgar é inerente ao ser humano. O que acontece são gradações distintas. O que define a excelência, a mediania, a mediocridade ou a má qualidade dos títulos de periódicos é exatamente a forma mais ou menos rígida, mais ou menos criteriosa, mais ou menos científica, como os artigos são analisados. Tal como ocorre com a seleção de trabalhos relatados em eventos científicos, os árbitros, na esfera das revistas, analisam o texto e elaboram parecer, tomando como referencial parâmetros fixados pelo editor junto com a comissão editorial. Dentre eles: adequação à linha editorial do título; marco conceitual e metodologia empregada coerentes com a proposta inicial; relevância das contribuições meritórias ou originais para a área; e redação aceitável.

No entanto, como natural, esse julgamento por pares apresenta pontos positivos e negativos, como admitem clássicos da editoração de 
periódicos científicos, que tem na publicação de C. T. Bishop, How to edit a scientific journal, 1984, a referência máxima, ainda hoje atual e em voga. De início, é possível questionar a confiabilidade, o valor e a necessidade do processo como um todo, alegando que a decisão de poucos sobre a produção de muitos é perigosa, porque acarreta efeitos que afetam a vida dos iniciantes, o status quo das especialidades e os rumos do saber. Por sua vez, pensar em divulgar todos os trabalhos à espera da aceitação ou repúdio da comunidade científica é comprometer a literatura científica e, por extensão, a ciência.

É certo que o processo avaliativo nunca é tranqüilo, nem nas áreas ditas exatas nem nas ciências sociais e humanas, nem para as revistas científicas impressas nem para as eletrônicas. Critérios externos, muitas vezes não declarados, influenciam o julgamento, com ênfase para a ingerência da opinião dominante dos cientistas de determinada área do conhecimento, época e lugar; o que tem a ver com o argumento de autoridade em ciência. É a predisposição de se aceitar como verdadeiras afirmações enunciadas por pessoas de prestígio, o que repercute na produção científica em geral, e em particular, na produção de artigos.

Editores e avaliadores tendem a acatar, sem tanto rigor, contribuições advindas dos "medalhões", enquanto os artigos oriundos de pesquisadores iniciantes ou vinculados a instituições de pequeno porte são metricamente analisados e dissecados. Por exemplo, Meadows (1999, p. 60) afirma que os "editores estão sempre ansiosos para garantir que os artigos sejam aceitos por seu mérito, e não porque seu autor tem renome". Porém, mais adiante, cita o caso dos membros da National Academy of Sciences, cujos trabalhos são publicados nos proceedings da Academia após revisão pro forma, porque se acredita que seus membros, como autores experientes (leia-se, famosos), têm consciência do que é um artigo aceitável.

Em outras palavras, se há queixas de autores e editores em relação aos avaliadores, o caminho inverso também é visível. Segundo Knobel (2003, p. 18), há assessores que contestam a publicação de trabalhos suspeitos e vetados por eles. Acrescentam que algumas grandes revistas favorecem a edição de artigos "considerados 'quentes', que venham a ser futuramente citados e que Ihes garantam a manutenção do prestígio." Por exemplo, ao publicar, no ano de 2001, em média um artigo a cada oito dias, em títulos importantes, como Science e Nature, sem levantar qualquer suspeita, o jovem Schön contou com a aquiescência e a cumplicidade (involuntária ou não) de editores e avaliadores.

Da mesma forma, no ano seguinte Science editou artigo de uma equipe norte-americana sobre fusão nuclear num becker de solvente orgânico, experimento posteriormente não comprovado. Em 1999, a revista Physical Review Letters veiculou artigo da equipe de Victor Ninov (laboratório norte-americano Lawrence Berkeley), no qual os físicos garantiam ter descoberto os elementos 116 e 118, o elemento existente mais pesado. No ano de 2001, o próprio grupo pediu a retirada do texto, alegando impossibilidade de replicação. Investigação posterior, no entanto, provou que os autores agiram de má-fé. Em abril de 2002, 
Nature suprimiu, oficialmente, artigo publicado no ano anterior acerca do DNA de plantações mexicanas de milho modificado geneticamente, neste caso, por "erro honesto", denominação incorporada ao novo código de conduta da Sociedade Americana de Física, de 2002: "O erro honesto é uma parte integral da ciência. Não é anti-ético (sic) estar errado, desde que os erros sejam rapidamente reconhecidos e corrigidos assim que detectados" (KNOBEL, 2003, p. 18).

Esses casos não negam a arbitragem como recurso responsável pelo padrão mínimo de qualidade às publicações científicas. Apenas apontam eventuais erros, aos quais se somam desvantagens inerentes ao sistema de avaliação em si, como a demora na edição dos artigos, os riscos de subjetivismo e parcialidade e a eventual elevação dos custos totais, face à infra-estrutura mínima indispensável: troca de e-mails, serviços de secretaria e despesas extras, além dos atrasos, que representam despesa adicional, com a ressalva de que os árbitros, em geral, descumprem prazos. Sobre eles, reforçamos que, salvo raríssimas exceções, não são remunerados. Há reiteradas sugestões para que isso ocorra, não somente como forma de imprimir rapidez ao julgamento, mas porque, além de questões alusivas à competitividade e a possíveis conflitos de interesse,

[...] muitos acham que, por se tratar de uma obrigação sem um retorno imediato, nem financeiro nem curricular, a maioria dos assessores apenas lêem os manuscritos superficialmente, sem se preocupar com a veracidade das informações ali contidas, e sem verificar publicações prévias dos autores do artigo submetido à publicação. (KNOBEL, 2003, p. 18).

Independente desses senões, os atores envolvidos com a produção de periódicos científicos, em geral, reconhecem a responsabilidade social do avaliador frente ao avanço da área a que pertence e à credibilidade das revistas. Estão em suas mãos os rumos de sua disciplina ou de campos afins, o que pressupõe que possui mais conhecimentos e / ou mais experiência do que os avaliados, além de ser capaz de exercitar, no cotidiano, os preceitos éticos intrínsecos à C\&T. Um avaliador ético pode discordar da linha teórica do artigo. Entretanto, não pode emitir parecer de recusa baseado apenas nessa condição. Consciente de que nem a ciência é dogma nem a verdade científica existe de forma perene, deve extrapolar a "repulsa" inicial para analisar os argumentos ou contraargumentos do autor.

É o pensamento propagado a partir de Popper (1972), de que a verificação em pesquisa não é para testar a validade, mas sim para identificar se existe falsidade. Em nenhum momento defendemos a falta de rigor científico. Em linha oposta, validamos a exatidão das observações, o rigor lógico e o detalhamento, básicos à ciência tanto quanto a criatividade e a imaginação. Mas, reiteramos: o avaliador de física ou de ciência da informação, de engenharia genética ou de sociologia, e assim sucessivamente, não pode se arvorar no direito de impor "suas" teorias e "seus" conceitos, desrespeitando os pares, a quem se concede o direito supremo de escolhas inerentes aos indivíduos e à familiaridade que possam ter com autores e métodos. E há, sempre, a 
possibilidade de não aceitar a incumbência. Esta é uma solução também para as ocasiões em que o árbitro não está a par dos avanços teóricos do objeto de pesquisa ou em que a temática não faz parte de seu repertório de conhecimento. Pode haver colegas mais familiarizados com o estado da arte daquela temática e prover parecer mais fundamentado (GARCIA, 2007).

Portanto, ao longo do processo de editoração ou, especificamente, de avaliação, o ideal é o comportamento ético integrado à consciência intelectual de cada um, advindo da prática de uma auto-ética no nível de autonomia individual, como idealizado por Morin (2005). Só assim é possível chegar à inferência de que os julgamentos de qualquer ordem, na vida pessoal e profissional, não comportam mal $\mathrm{x}$ bem ou certo $\mathrm{x}$ errado. Inexistem unanimidade e conclusão finalista na produção do conhecimento. Repetindo Popper (1972), teses e resultados têm "prazo de validade" até sua substituição. Esse processo dialético de construção e renovação, de fazer e refazer constitui a essência da C\&T e se impõe como garantia para a evolução da ciência.

Como decorrência, e em resposta a dois outros questionamentos de Greene (1999) - O editor responsável pode descumprir o prescrito pelos assessores? / O editor responsável deve adotar padrões aprovados pelos comitês de avaliação? - é indiscutível que o editor deve cumprir o decidido pelos avaliadores, não obstante as denúncias de trabalhos vedados e, mesmo assim, publicados. (KNOBEL, 2003). Compete ao editor seguir à risca as recomendações e, se for o caso, acatar sugestões. Desrespeitar as decisões dos colaboradores corresponde a negar a função decisiva da avaliação, descrita em detalhes por Bishop (1984) como essencial à sobrevivência dos títulos científicos como credíveis e respeitados, junto à comunidade científica, à sociedade em geral e, em especial, às agências de fomento e às instituições mantenedoras.

E mais, a avaliação interfere na qualidade dos artigos antes mesmo da submissão, ou seja, desde a fase de elaboração. Diante da expectativa de serem julgados, com freqüência os pesquisadores mostram-se mais cuidadosos e, em geral, os manuscritos modificados segundo a percepção dos árbitros apresentam melhor qualidade. Porém, a bem da verdade, este também é um ponto controverso no universo da produção de periódicos e artigos científicos. Há quem atribua à arbitragem efeito inibidor no avanço das especialidades, por conta da propensão para se aprovar artigos que reforcem os paradigmas vigentes e rejeitar textos "revolucionários", que ponham em xeque os conhecimentos estabelecidos, a despeito do estímulo dos editores para que os autores inovem e apresentem contra-argumentos às "verdades" enunciadas. A explicação pode estar no fato de que os avaliadores, grosso modo, são mais velhos, com interesse em linhas de pesquisa estabelecidas, ou são mais resistentes a mudanças. Exemplificando, segundo Meadows (1999), a revista Nature, em que pese sua respeitabilidade, no intervalo entre as duas guerras mundiais, rejeitou três dos maiores avanços científicos do século $X X$. 
Há, no entanto, recomendações fáceis de seguir. Manter os avaliadores por tempo determinado no corpo de pareceristas da revista, renovando-os continuamente, ou convidar avaliadores ad hoc, sempre que preciso. Acrescentamos que as TICs tanto facilitam a identificação de fraudes, como Tantam (1991) constata, como agilizam os procedimentos avaliativos, graças ao feedback quase instantâneo, além da chance de mais eficiência, mais transparência e maior validação. Além disso, agora é viável uma distribuição mais eqüitativa. A seleção dos árbitros pode seguir plano abrangente e universal, que reduz o risco de "contaminação", incluindo nomes presentes em surveys, boletins de discussão, citações bibliográficas, além de aceitar possíveis voluntários, não importando localização geográfica. Isto amplia as chances de participação de cientistas ou pesquisadores de países menos desenvolvidos, no caso das revistas internacionais, ou de envolvimento de profissionais das regiões menos favorecidas economicamente, no caso do Brasil.

Outro item positivo é a velocidade com que os manuscritos podem ser enviados eletronicamente para apreciação, somada à conveniência de leitura, análise e comentário na tela, para muitos estudiosos. As possibilidades via espaço cibernético ainda fazem mais: evitam o desgaste dos avaliadores, que são sistematicamente convidados, e permitem aos editores substituírem aqueles que emitem pareceres sem muita qualidade (a citada avaliação descuidada). Se, por um lado, esses especialistas não criam discordâncias, por outro, passam a nítida impressão de que o respeito e a importância concedida ao autor, ao artigo e ao periódico são mínimos ou inexistentes, configurando-se como atitude distante da responsabilidade ética e social que se espera do avaliador, enquanto juiz.

\section{Palavras finais: questões e soluções em aberto}

Como as colocações de G. Fourez, Edgar Morin e Letícia Helena Medeiros Veloso deixam antever, as questões éticas alcançam todos os setores da vida em sociedade, incluindo a política, a religião, a indústria etc. Mesmo quando restringimos a discussão à produção intelectual e cultural, nos defrontamos com casos de violação dos ditames éticos. Por exemplo, na literatura, apesar da defesa pública da escritora Ana Miranda em relação às denúncias de Antonio Alcir Bernardes Pécora sobre a apropriação de trechos do original da Carta Ânua, de Padre Antônio Vieira, em seu romance Boca do inferno. Dentre a polêmica acirrada, à época, restou a certeza de quão difícil é traçar os limites éticos da criação ficcional. No jornalismo, o caso de repercussão internacional mais recente diz respeito ao falsário norte-americano Jayson Blair, repórter do jornal mais conhecido dos Estados Unidos, o New York Times, demitido em maio de 2003 por forjar inúmeras matérias e reportagens.

Em se tratando da produção científica e do caso específico de artigos e periódicos, há facetas complexas, distintas e diversificadas, envolvendo, sobretudo, autores, editores e avaliadores, como discutido. Na esfera da autoria, há que se rever os procedimentos aéticos que, às vezes, cercam a co-autoria. Para Targino (2005), no âmbito nacional, a banalização e o 
desrespeito à autoria têm origem ainda no ensino fundamental e médio e prossegue na educação superior. São os célebres trabalhos de equipe, onde constam nomes alheios à sua construção. São as denúncias freqüentes de plágio em monografias de final de curso de graduação. No primeiro semestre de 2005, em Teresina, Piauí, o corpo docente de uma IES particular detectou a tempo fraude em 12 dos 24 trabalhos finais da primeira turma de jornalismo. Künzel (2003, não paginado), referindo-se ao contexto do Paraná, diz:

As maneiras como o plágio se apresenta nos trabalhos acadêmicos são variadas. Vão de trechos e capítulos inteiros de livros especializados a cópias parciais ou até integrais de monografias e teses de mestrado, disponíveis na internet e bibliotecas dos cursos. Tem aluno que faz de um capítulo de livro sua monografia. Copia integralmente o que o autor do original escreveu, colocando parte do texto como citação, para disfarçar $[\ldots]$.

São exemplos, dentre uma infinidade de outros, que mostram o risco desses jovens alcançarem a pós-graduação ou conquistarem o status de pesquisadores ou autores, sem discernirem os limites éticos da produção científica. Verdade que isso não refuta a relevância da co-autoria responsável. Meadows (1999) ressalva que ela sempre existiu. Cita casos clássicos: a descoberta sobre o DNA, em 1953, por Francis Crick e James Watson ou a obra de Bourbaki, pseudônimo utilizado por um grupo de matemáticos predominantemente franceses, em 1939, para divulgar seus trabalhos. Na verdade, a autoria múltipla começa a aparecer com mais freqüência na primeira metade do século $X X$, e, tal como o peer review, ganha expressão após a Segunda Guerra Mundial, sobretudo na física nuclear e na ciência espacial.

Na atualidade, no Brasil, a difusão da co-autoria é incentivada pelas agências de fomento visando à formação de grupos de pesquisa e à produção coletiva. Esta, ainda para Meadows (1999), em termos genéricos, consegue maior visibilidade, graças ao número elevado de citações que os trabalhos em grupo tendem a receber. $E$ mais, têm chance de melhor qualidade, porque, em geral, envolvem cientistas produtivos e de renome, permitindo a troca de informação entre vários especialistas, o que favorece maturação de idéias e maior atenção para o deslanchar da investigação.

Ao lado desses aspectos positivos, a co-autoria mantém uma face obscura. São casos de co-autores para mera ascensão funcional; cumprimento de exigências burocráticas; imposições de orientadores ante orientandos; troca de favores entre colegas e companheiros de trabalho; pressão profissional e social para publicar, graças a um sistema que credita a quem mais publica maior facilidade na aprovação de projetos e no recebimento de financiamentos e, então, maior rendimento financeiro. Enfim, são nuanças "ricas" e questionáveis do ponto de vista da responsabilidade ética e social. 
Trata-se de um sistema que focaliza duas responsabilidades: de um lado, a produtividade do pesquisador, traduzida em indicadores quantitativos; do outro, a produtividade com menor qualidade, em meio a resultados que, em algumas situações, desconsideram o conhecimento genuíno, criativo e teórico e a diferença temporal de produção em algumas áreas, conduzindo à simplificação e inconsistência de conteúdos. Ora, em qualquer situação, autoria e co-autoria pressupõem a participação efetiva em todas as etapas de produção e não sinalizam para o parasitismo intelectual ou para a autoria irresponsável. E mais, no caso do flagrante delito do alemão Hendrik Schön, o comitê de investigação não detectou regras éticas claras sobre a co-autoria e isentou os demais membros da equipe de qualquer punição. Knobel (2003, p. 18) pergunta, com veemência: [...] é justo que os co-autores dividam as glórias, mas que não se responsabilizem caso algo ruim ocorra?

Diante da complexidade dos aspectos envolvidos, parece óbvio que a sexta e última pergunta de Greene (1999) - Como o editor responsável pode evitar conflitos? - não tem resposta unívoca. Resta manter contato permanente com autores e avaliadores, para garantir o êxito da editoração dos artigos e revistas científicas, amoldando as decisões em consonância com as situações particulares. Tomar decisões em qualquer nível não é tarefa fácil. Há sempre o risco de acerto e / ou de erro, de atendimento a uns e de desagrado a outros. No entanto, qualquer ser humano obriga-se a elas e mais ainda quem assume atividades de gestão de uma revista científica. Portanto, as decisões relativas à produção editorial têm seu custo e nunca são simples. Afinal, o mundo do conhecimento é constituído por seres humanos e, assim sendo, permeado por informações. Seres humanos, por sua vez, assumem atitudes ambíguas: a vaidade do título acadêmico de uns se contrapõe à humildade de outros; a prepotência de alguns destoa da gentileza de pessoas disponíveis e que socializam seu saber.

Ao editor compete desenvolver capacidade ética quase ilimitada para comunicar a uns e a outros notícias alvissareiras ou "agoureiras", dentre pareceres favoráveis ou desfavoráveis, dentre sugestões de pequenas mudanças ou profundas alterações. Há histórias maravilhosas vividas e contadas por editores. Há histórias sofridas vividas e contadas por editores. Há de tudo, nessa tentativa de vencer os dilemas que perpassam o ciclo da produção editorial, imbricando-se e iniciando-se com as idéias dos autores, traduzidas em textos, submetidos às editoras, passando pelas etapas de avaliação e de produção, concluindo com a disponibilidade da obra ao público e à disputa do mercado.

Ao reportar-se à situação brasileira, Veloso (2006) reconhece conflito entre dois traços culturais enraizados: de um lado, um que valoriza a idoneidade das relações sociais; do outro, a lógica do "jeitinho brasileiro". Mas a cultura organizacional nacional está sofrendo mutações. A responsabilidade social sofre interveniências da globalização e da revolução digital. No ambiente de trabalho, as questões de poder estão sendo questionadas. A articulação entre política e ciência é fundamental, de forma que a difusão da ciência e a produção científica assumem 
relevância vital. Numa sociedade marcada pelo predomínio da C\&T, a divulgação científica tem nítidas repercussões sociopolíticas, como Fourez (1995) reitera. Então, mais uma vez, afirmamos: há de tudo. Há artigos aceitos, na íntegra. Há artigos recusados in totum. Há artigos para os quais são solicitadas modificações, sem necessidade de retorno para os avaliadores. Há artigos que requerem nova submissão.

Diante desse território "movediço", compete ao editor caminhar entre autores e avaliadores mediante postura humana suscetível de ser qualificada como ética. Deve primar por regras de conduta impregnadas de respeito, dentro da ética da cordialidade estimulada por Morin (2005). Ambas as categorias são imprescindíveis à sobrevivência dos periódicos. Os avaliadores the auxiliam, substancialmente. Sem autores, não há edição. Isso reitera a relevância de cada segmento, com vistas a cumprir a periodicidade e a regularidade de publicação.

E a cada novo fascículo, a luta se renova. Surgem novos dilemas e novas responsabilidades, cada um a exigir decisões específicas. É a confirmação das premissas de Fourez (1995) e de Veloso (2006), quando insistem que, diante da utopia de códigos de ética que comportem todas as situações presumíveis, ou diante das incertezas éticas de que fala Morin (2005), as responsabilidades éticas e sociais devem seguir os critérios socialmente éticos ou socialmente responsáveis na esfera de cada realidade. Sob este olhar, ser editor de periódico técnico-científico é encetar luta diária e suplantar dilemas em favor da responsabilidade social e da ética para concluir o processo de produção científica, finalizando por divulgar os resultados de pesquisa e fazer circular os conhecimentos gerados em prol das coletividades.

Autor, editor e avaliador, junto com os demais partícipes da editoração, assumem responsabilidade social perante o avanço da ciência, porque a publicação é uma espécie de prestação de contas à sociedade, no que concerne aos insumos recebidos. É o coroamento de um trabalho coletivo levado a público, que se caracteriza como atividade vital à divulgação da ciência para que outros a absorvam e a transmutem, num ciclo contínuo e inesgotável. Por tudo isso, diante das injunções impostas pela globalização, da maior visibilidade dos princípios éticos e dos valores morais, da complexidade crescente dos contextos culturais, não há como desmerecer o trabalho de produção científica e das revistas técnicocientíficas, em especial.

Na condução do processo de divulgação, cabe a autores, editores e avaliadores adotarem acima de tudo a prática da auto-ética, de forma a atingir a ética para com o outro. Todos devem estar conscientes da utopia de julgamentos uníssonos, tais como ocorrem com fatos do cotidiano, com maior ou menor repercussão midiática. Daí, finalizarmos com questões e soluções em aberto. Exemplificando: que respostas são possíveis, em termos de produção de periódicos, quando nos defrontamos com estes questionamentos:

Por enquanto, o plágio ainda é condenado pela ética sobrevivente como fraude intelectual e uma apropriação do 
trabalho e do mérito alheios. Mas já há sites [...] dedicados [...] à venda de pesquisas [...] Um novo hábito. Costumes criam valores. Que tipo de valores este criará? Que tipo de ética? (KUCINSKI, 2005, não paginado, grifos nossos).

O próprio sistema de incentivos à pesquisa e a competitividade impelem à publicação rápida e em quantidade considerável. Qual é o limite? (KNOBEL, 2003, p. 18, grifos nossos).

O que é autocitação moderada? (TARGINO, 2005, grifos nossos).

\section{Referências}

ALTMAN, F. Trombada universitária. Veja, São Paulo, p. 93, 26 out. 1994.

ANTONIO, I. Autoria y cultura posmoderna. Acimed, [S. I.], n. 9, 2001. Disponível em <http://bvs.sld.cu/revistas/ aci>. Acesso em: 12 fev. 2008.

BARTHES, R. A morte do autor. In: O rumor da língua. São Paulo: Brasiliense, 1998. p. 65-70.

BISHOP, C. T. How to edit a scientific journal. Philadelphia: ISI, 1984.

DAVYT, A.; VELHO, L. A avaliação da ciência e a revisão por pares: passado e presente. Como será o futuro? História, Ciências, Saúde, Rio de Janeiro, v. 7, n.1, p. 93-116, mar. / jun. 2000.

ECO, U. Obra abierta. Barcelona: Ariel, 1990.

ESTE homem é um farsante. Veja, São Paulo, n. 1938, 11 jan. 2006. (Seção Medicina).

FOUCAULT, M. O que é um autor? 2 ed. Lisboa: Vega, 1992.

FOUREZ, G. Como articular ciência e ética? In:

- A construção das ciências: introdução à filosofia e à ética das ciências. São Paulo: Unesp, 1995. p. 297-306.

GARCIA, J. C. R. Responsabilidade social com a ciência. Datagramazero, Rio de Janeiro, v.8, n.2, abr. 2007. Disponível em: <http://www.dgz.org.br>. Acesso em: 12 fev. 2008.

GREENE, L. J. Dilemas do editor. In: WORKSHOP PARA EDITORES DE REVISTAS CIENTÍfICAS, 2., 1999, Petrópolis, Separata... Petrópolis: ABEC, 1999.

KNOBEL, M. Fraudes sacodem a comunidade científica. Ciência e Cultura, São Paulo, v. 55, n. 3, p. 17-18, jul. / set. 2003.

KOCHAN, C. A.; BUDD, J. M. The persistence of fraud in literature: the Darsee case. Journal of the American Society for Information Science, New York, v. 43, n. 7, p. 488-493, 1992.

KUCINSKI, B. Jornalismo na era virtual. São Paulo: Fundação Perseu Abramo / Unesp, 2005. 
KÜNZEL, P. Plágio em monografia expõe falha da avaliação no ensino superior. Gazeta do Povo, Curitiba, 24 mar. 2003 (não paginado).

LE COADIC, Y.-F. A ciência da informação. Brasília: Briquet de Lemos/Livros, 1996.

MEADOWS, A. J. A comunicação científica. Brasília: Briquet de Lemos Livros, 1999.

MORIN, E. O método 6: ética. Porto Alegre: Sulina, 2005.

PACKER, A. L.; MENEGHINI, R. Visibilidade da produção científica. In: POBLACION, D. A.; WITTER, G. P.; SILVA, J. F. M. da. Comunicação \& produção científica: contexto, indicadores e avaliação. São Paulo: Angellara, 2006. p. 237-259.

POPPER, K. R. Conjecturas e refutações: o processo do conhecimento científico. 4. ed. Brasília: Ed. Universidade de Brasília, 1972.

ROUSSEAU, J. J. Do contrato social. Campinas: Russell, 2006.

TANTAM, M. The impact of computers on the investigation of fraud: the Serious Fraud Office experience. The Law Librarian, [S. I.], v. 22, n. 1, p. 2-6, Apr. 1991.

TARGINO, M. das G. Artigos científicos: a saga da autoria e co-autoria. In: FERREIRA, S. M. S. P.; TARGINO, M. das G. (Org.). Preparação de revistas científicas: teoria e prática. São Paulo: Reichmann \& Autores Ed., 2005. p. 35-54.

VELOSO, L. H. M. Ética, valores e cultura: especificidades do conceito de responsabilidade social corporativa. In: ASHLEY, P. A. (Org.). Ética e responsabilidade social nos negócios. 2. ed. São Paulo: Saraiva, 2006. p. 2-16.

WILSON, T. D. A problemática da gestão do conhecimento. In: TARAPANOFF, K. (Org.). Inteligência, informação e conhecimento. Brasília: IBICT, Unesco, 2006. 